\title{
Alicyclobacillus pomorum sp. nov., a novel thermo-acidophilic, endospore-forming bacterium that does not possess $\omega$-alicyclic fatty acids, and emended description of the genus Alicyclobacillus
}

\author{
Keiichi Goto, ${ }^{1}$ Kaoru Mochida, ${ }^{1}$ Mika Asahara, ${ }^{1}$ Masayuki Suzuki, ${ }^{2}$ \\ Hiroaki Kasai ${ }^{3}$ and Akira Yokota ${ }^{4}$ \\ 1,2Microbiological and Analytical Group, Food Research Laboratories, Mitsui Norin Co. Ltd ${ }^{1}$ \\ and Central Research Laboratories, Tokyo Food Techno Co. Ltd², 223-1, Miyahara, Fujieda, \\ Shizuoka 426-0133, Japan \\ ${ }^{3}$ Marine Biotechnology Institute, 3-75-1, Heita, Kamaishi, Iwate 026-0001, Japan \\ ${ }^{4}$ Institute of Molecular and Cellular Biosciences, University of Tokyo, 1-1, Yayoi 1-chome, \\ Bunkyo-ku, Tokyo 113-0032, Japan
}

Correspondence Keiichi Goto kgoto@mnk.co.jp
The genus Alicyclobacillus (Wisotzkey et al., 1992) consists of a group of thermo-acidophilic, strictly aerobic, heterotrophic, endospore-forming bacteria. The genus originally consisted of three species, Alicyclobacillus acidocaldarius, Alicyclobacillus acidoterrestris and Alicyclobacillus cycloheptanicus. In recent years, four novel species and one subspecies have been formally assigned to the genus; Alicyclobacillus hesperidum (Albuquerque et al., 2000), Alicyclobacillus herbarius (Goto et al., 2002a), Alicyclobacillus acidiphilus (Matsubara et al., 2002), Alicyclobacillus sendaiensis (Tsuruoka et al. 2003) and Alicyclobacillus acidocaldarius subsp. rittmannii (Nicolaus et al., 1998). In

Published online ahead of print on 21 March 2003 as DOI 10.1099/ ijs.0.02546-0.

The DDBJ/GenBank/EMBL accession numbers for the $16 \mathrm{~S}$ rDNA and gyrB gene sequences are AB089840-AB089859. addition, two genomic species, Alicyclobacillus genomic species 1 (Albuquerque et al., 2000) and Alicyclobacillus genomic species 2 (Goto et al., 2002b), have been reported as genomic species of A. acidocaldarius. All Alicyclobacillus species form one phylogenetic cluster (exclusive of the species Sulfobacillus disulfidooxidans) based on 16S rDNA sequence analysis and possess $\omega$-alicyclic fatty acids ( $\omega$-cyclohexane or $\omega$-cycloheptane fatty acids) as the major membrane lipid component. The Alicyclobacillus species have been isolated from natural sources such as hot springs and soil (Uchino \& Doi, 1967; Darland \& Brock, 1971; Hippchen et al., 1981; Deinhard et al., 1987a, b; Hiraishi et al., 1997; Nicolaus et al., 1998; Albuquerque et al., 2000; Goto et al., 2002b, Tsuruoka et al. 2003), as well as secondary spoiled fruit-based beverages (Yamazaki et al., 1996; Goto et al., 2002a; Matsubara et al., 2002). During the course of a microbiological survey of various fruit juices, we 
isolated an unusual Alicyclobacillus-like organism from a spoiled mixed fruit juice. Based on the results of a polyphasic taxonomic study, a novel and anomalous species of the genus Alicyclobacillus, Alicyclobacillus pomorum sp. nov., is described here.

Strain $3 \mathrm{~A}^{\mathrm{T}}$ was isolated from a spoiled mixed fruit juice (containing fresh orange, apple, mango, pineapple and raspberry juice imported into Japan from the USA) by using the dilution plating technique on a solid medium (YSG agar) containing $\left(1^{-1}\right) 2 \mathrm{~g}$ yeast extract, $1 \mathrm{~g}$ glucose, $2 \mathrm{~g}$ soluble starch and $15 \mathrm{~g}$ agar $\left(\mathrm{pH} 3.7\right.$ with $1 \mathrm{M} \mathrm{H}_{2} \mathrm{SO}_{4}$ ). Other species isolated at the same time were Bacillus subtilis, Lactobacillus plantarum, Lactobacillus brevis, Saccharomyces cerevisiae and Saccharomyces pastorianus. Based on partial $16 \mathrm{~S}$ rDNA sequence analyses (Goto et al., 2000, 2002c), the strain was grouped into the Alicyclobacillus cluster. The strain, however, was found to be distinct from previously described species of the genus Alicyclobacillus.

To investigate the morphological and physiological characteristics of strain $3 \mathrm{~A}^{\mathrm{T}}$, it was cultured in Bacillus acidocaldarius medium (BAM; Deinhard et al., 1987a) at $45^{\circ} \mathrm{C}$. Arthrobacter globiformis JCM $1332^{\mathrm{T}}$, Bacillus tusciae IFO $15312^{\mathrm{T}}$, Sulfobacillus acidophilus DSM $10332^{\mathrm{T}}$, Sulfobacillus disulfidooxidans DSM $12064^{\mathrm{T}}$ and Sulfobacillus thermosulfdooxidans DSM $9293^{\mathrm{T}}$ were also cultivated according to the methods recommended in the corresponding DSM and IFO strain catalogues. Alicyclobacillus acidiphilus TA67 was kindly provided by Motohiro Niwa (Kirin Beverage Corporation, Samukawa-machi, Kanagawa, Japan). Unless indicated otherwise, all morphological and physiological tests have been described in a previous study (Goto et al., 2002a). Since the strain did not grow in the presence of indicators, the degree of acidification was determined by measuring the $\mathrm{pH}$ decrease $(>0 \cdot 4)$ of the culture using BAM basal salts medium without indicator to which a carbon source $\left(2 \mathrm{~g} \mathrm{l}^{-1}\right)$ was added. Acidification was observed every day for 7 days and the reading showing the strongest acidification was recorded. All tests were repeated in triplicate.

Cellular fatty acid analysis, menaquinone analysis and the preparation of DNA have been described in previous studies (Goto et al., 2000, 2002a). The DNA G + C content was determined by the method of Tamaoka et al. (1984) using HPLC with a YMC-Pack ODS-AQ AQ302 column $(4 \cdot 6 \times 150 \mathrm{~mm} ; \mathrm{YMC})$ and $10 \mathrm{mM} \mathrm{H}_{3} \mathrm{PO}_{4} / 10 \mathrm{mM} \mathrm{KH}_{2} \mathrm{PO}_{4}$ ( $\mathrm{pH} 3.5)$ as the mobile phase. Almost complete $16 \mathrm{~S}$ rDNA sequences were determined using the $16 \mathrm{~S}$ rRNA Gene Kit following the protocols of the manufacturer (Applied Biosystems). DNA-DNA hybridization experiments were performed by the method of Ezaki et al. (1989) using photobiotin-labelled DNA probes and microplates.

Nucleotide sequences of gyrB genes were determined directly from PCR fragments amplified by the methods described by Yamamoto \& Harayama (1995) and Kasai et al. (2000). The primers used for $g y r B$ gene amplification were
UP-1G (forward: 5'-GAAGTCATCATGACCGTTCTGCAYGCNGGNGGNAARTTYGG-3') and UP-2r (reverse: $5^{\prime}$ AGCAGGGTACGGATGTGCGAGCCRTCNACRTCNGCRTCNGTCAT-3'). Primer UP-1G annealed at positions 274-314 and primer UP-2r annealed at positions 1486-1529 (relative to Escherichia coli K-12 gene numbering). The amplified products were purified by gel electrophoresis on $0.8 \%$ low-melting-point agarose (SeaPlaque GTG; FMC Bioproducts). The purified fragments were recovered from the agarose by a QIAquick gel extraction kit (Qiagen). Sequencing was carried out with an ABI PRISM Dye Terminator Cycle Sequencing Kit with sequencing primers UP-1S (forward: 5'-GAAGTCATCATGACCGTTCTGCA3'; positions 274-296), gyrS-2F (reverse: 5'-GAACAAGCSTTTTTRAATKCCGG-3'; positions 577-599), gyr-Int-R (reverse: 5'-CCGCGVACYTCRCTGTTGCC-3'; positions 1021-1040), gyrS-4R (reverse: 5' -GATTCCAGYACRCTTTTTCGCCG-3'; positions 1177-1199) and UP-2rS (reverse: 5'-AGCAGGGTACGGATGTGCGAGCC-3'; positions 15071529). The products were analysed by an ABI PRISM 3100 Genetic Analyser (Applied Biosystems) according to the manufacturer's instructions.

Sequence analysis was performed using Gene Works (version 2.0; IntelliGenetics) and the GenBank/EMBL/ DDBJ databases. Multiple sequence alignment was performed using CLUSTAL $\mathrm{W}$ version 1.8 (Thompson et al., 1994). Also, the gyrB gene sequences and their deduced amino acid sequences were aligned by CLUSTAL $\mathrm{W}$ version 1.8 and the alignments were manually corrected. Alignment gaps and unidentified base positions were not taken into account for these calculations. A phylogenetic reconstruction was produced using MEGA2 (Kumer et al., 2001) with the following settings: neighbour-joining (Saitou \& Nei, 1987) based on Kimura's two-parameter model (Kimura, 1980) and maximum-parsimony (Lake, 1987) methods. The robustness of individual branches was estimated by bootstrapping with 1000 replicates (Felsenstein, 1985). The DDBJ accession numbers of $16 \mathrm{~S}$ rDNA and gyrB gene sequences used for each phylogenetic analysis are shown in Fig. 1 and Fig. 2, respectively.

Cells of strain $3 \mathrm{~A}^{\mathrm{T}}$ were Gram-positive, but Gram-variable in old cultures, motile rods $(2 \cdot 0-4 \cdot 0 \times 0 \cdot 8-1 \cdot 0 \mu \mathrm{m})$ and formed oval spores subterminally in swollen sporangia. Colonies were flat, smooth and creamy white after $48 \mathrm{~h}$ culture on BAM agar. Growth of strain $3 \mathrm{~A}^{\mathrm{T}}$ occurred aerobically at 30 and $60^{\circ} \mathrm{C}$, but not at 25 or $65^{\circ} \mathrm{C}$. The optimal growth temperature was in the range of $45-50{ }^{\circ} \mathrm{C}$. Strain $3 \mathrm{~A}^{\mathrm{T}}$ grew well at $\mathrm{pH} 4 \cdot 0-4 \cdot 5$ with growth inhibited at $\mathrm{pH} 2.5$ and 6.5 . The strain failed to grow on BAM containing more than $2 \%(\mathrm{w} / \mathrm{v}) \mathrm{NaCl}$. No growth occurred under anaerobic conditions. Strain $3 \mathrm{~A}^{\mathrm{T}}$ could grow heterotrophically in an inorganic medium containing glucose or starch, without any growth factors. The generation time in BAM at $45^{\circ} \mathrm{C}$ was approximately $1.5 \mathrm{~h}$. Strain $3 \mathrm{~A}^{\mathrm{T}}$ had catalase and oxidase activities, but no nitrate reductase activity. Aesculin, starch and gelatin were hydrolysed, but 


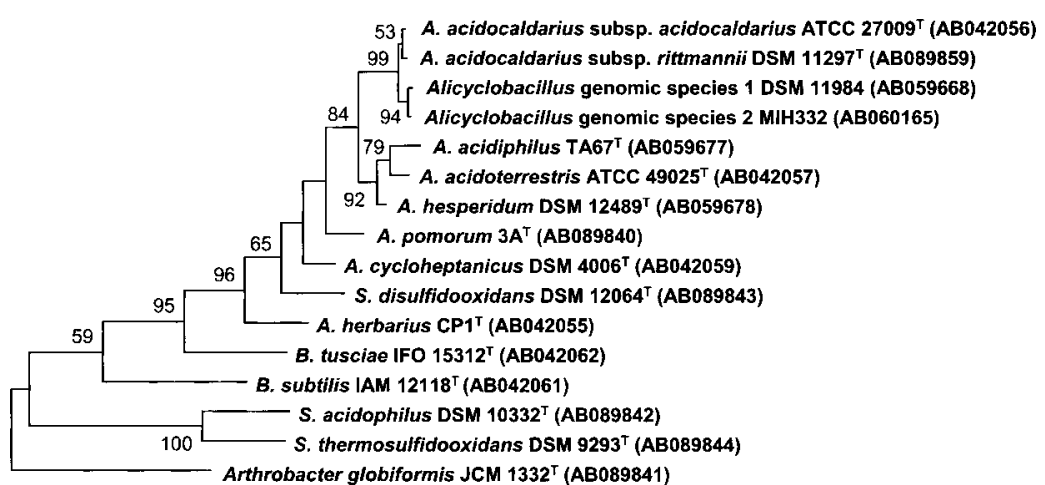

Fig. 1. Phylogenetic tree (constructed using the maximum-parsimony method) derived from an alignment comprising 16S rDNA sequences from phylogenetically related Alicyclobacillus, Bacillus and Sulfobacillus species. Arthrobacter globiformis JCM $1332^{\top}$ served as outgroup. The final dataset included 1392 unambiguously aligned sites. Numbers represent percentages from 1000 replicate bootstrap samplings (frequencies of less than $50 \%$ are not shown). no hydrolysis of arbutin, phenylalanine or tyrosine was observed. Acid was produced from glycerol, ribose, D-glucose, D-fructose, D-mannose, L-sorbose, mannitol, methyl- $\alpha$-D-glucoside, amygdalin, aesculin, salicin, maltose, sucrose, trehalose, D-turanose, D-tagatose and 5-ketogluconate. The differential phenotypic characteristics of strain $3 \mathrm{~A}^{\mathrm{T}}$ and Alicyclobacillus reference strains are shown in Table 1.

The major respiratory quinone of strain $3 \mathrm{~A}^{\mathrm{T}}$ was menaquinone-7 (MK7), which accounted for $97 \%$ of the total, with MK3 as the vestigial quinone (3\%). The fatty acid profile of strain $3 \mathrm{~A}^{\mathrm{T}}$ consisted mainly of iso- and anteisobranched acids combined with a small amount of straightchain saturated $\left(\mathrm{C}_{16: 0}\right.$ and $\left.\mathrm{C}_{18: 0}\right)$ acids (Table 2$)$. In the absence of $\omega$-alicyclic fatty acids, the fatty acid profile of strain $3 \mathrm{~A}^{\mathrm{T}}$ is clearly different from that of Alicyclobacillus species and thus it is more similar to that of Bacillus tusciae. However, significant differences in the level of iso- $\mathrm{C}_{15: 0}$, anteiso- $C_{15: 0}$, iso- $C_{16: 0}$ and iso- $C_{18: 0}$ distinguished strain $3 \mathrm{~A}^{\mathrm{T}}$ from $B$. tusciae. The $\mathrm{G}+\mathrm{C}$ content of strain $3 \mathrm{~A}^{\mathrm{T}}$ was $53 \cdot 1 \mathrm{~mol} \%$, which is in the range for known Alicyclobacillus species (53-63\%) and Sulfobacillus species (52-56\%).

The near complete 16S rDNA sequences between positions 37 and 1476 (Escherichia coli numbering; Brosius et al., 1978) for strains $3 \mathrm{~A}^{\mathrm{T}}$, Alicyclobacillus acidocaldarius subsp. rittmannii DSM $11297^{\mathrm{T}}$, Arthrobacter globiformis JCM $1332^{\mathrm{T}}$, Sulfobacillus acidophilus DSM $10332^{\mathrm{T}}$, Sulfobacillus disulfidooxidans DSM $12064^{\mathrm{T}}$ and Sulfobacillus thermosulfidooxidans DSM $9293^{\mathrm{T}}$ were determined. These sequences were aligned with published sequences available from the
GenBank/EMBL/DDBJ databases and the phylogenetic position of strain $3 \mathrm{~A}^{\mathrm{T}}$ was inferred by constructing a phylogenetic tree with either the neighbour-joining method (data not shown) or the maximum-parsimony method (Fig. 1). The phylogenetic analyses, based on 1392 unambiguous nucleotides, showed that strain $3 \mathrm{~A}^{\mathrm{T}}$ fell within the cluster composed of Alicyclobacillus species and Sulfobacillus disulfidooxidans DSM $12064^{\mathrm{T}}$ in both trees and that the cluster was supported by high bootstrap values of $99 \%$ (neighbour-joining tree) and 95\% (maximum-parsimony tree), respectively. However, strain $3 \mathrm{~A}^{\mathrm{T}}$ did not show a close relationship with any other species of the cluster. The same results were obtained when the phylogenetic tree was constructed based on a wider sample of species (available as supplementary material in IJSEM online at http://ijs. sgmjournals.org/). The sequence similarity values between strain $3 \mathrm{~A}^{\mathrm{T}}$ and other strains of the cluster exceeded $92 \%$, this being the lower limit for Alicyclobacillus species (Wisotzkey et al., 1992). Similarity values between strain $3 \mathrm{~A}^{\mathrm{T}}$ and Bacillus tusciae IFO $15312^{\mathrm{T}}$, Sulfobacillus acidophilus DSM $10332^{\mathrm{T}}$ or S. thermosulfidooxidans DSM $9293^{\mathrm{T}}$ were all below $90 \%$ (Table 3 ).

The partial gyrB nucleotide sequences, comprising at least $1164 \mathrm{bp}$, for strain $3 \mathrm{~A}^{\mathrm{T}}$, nine Alicyclobacillus strains, Bacillus tusciae IFO $15312^{\mathrm{T}}$ and three Sulfobacillus strains were determined. Phylogenetic analyses, based on the alignment of gyrB gene sequences (1146 nucleotides between Escherichia coli positions 316 and 1485; Adachi et al., 1987), showed that strain $3 \mathrm{~A}^{\mathrm{T}}$ formed a monophyletic cluster with $\mathrm{Ali}$ cyclobacillus species and Sulfobacillus disulfidooxidans DSM $12064^{\mathrm{T}}$ in both the neighbour-joining tree (data not shown)

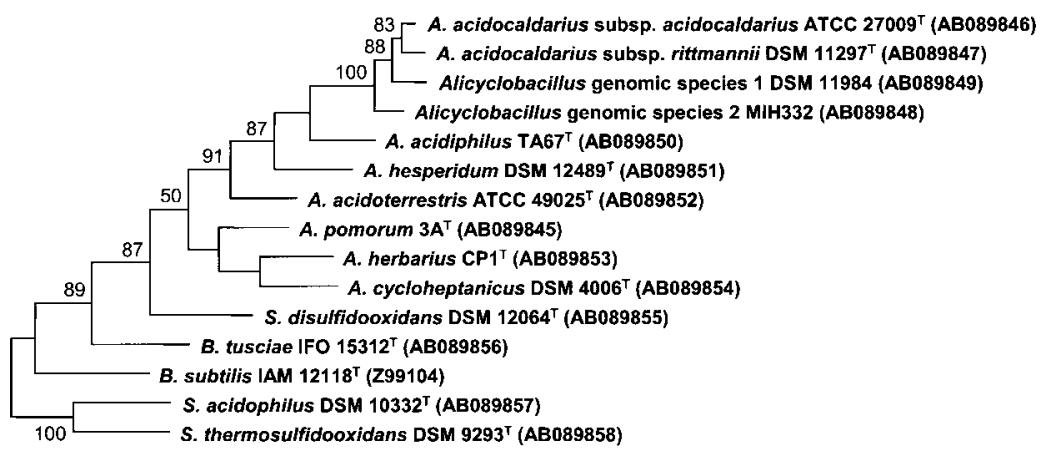

Fig. 2. Phylogenetic tree (constructed using the maximum-parsimony method) showing the phylogenetic position of strain $3 A^{\top}$ in relation to phylogenetically related Alicyclobacillus, Bacillus and Sulfobacillus species, based on gyrB gene sequences. Sulfobacillus thermosulfidooxidans DSM $9293^{\top}$ served as outgroup. The final dataset included 1161 unambiguously aligned sites. Numbers represent percentages from 1000 replicate bootstrap samplings (frequencies of less than $50 \%$ are not shown). 
Table 1. Differential characteristics of Alicyclobacillus pomorum $3 A^{\top}$ and related Alicyclobacillus strains

Strains: 1, Alicyclobacillus pomorum $3 \mathrm{~A}^{\mathrm{T}}$; 2, Alicyclobacillus acidocaldarius ATCC $27009^{\mathrm{T}}$; 3, Alicyclobacillus genomic species 1 DSM 11984; 4, Alicyclobacillus genomic species $2 \mathrm{MIH} 332 ; 5$, Alicyclobacillus acidoterrestris ATCC 49025 $;$, 6, Alicyclobacillus hesperidum DSM 12489 ${ }^{\mathrm{T}}$; 7, Alicyclobacillus acidiphilus TA67 ${ }^{\mathrm{T}}$; , Alicyclobacillus cycloheptanicus DSM 4006; 9, Alicyclobacillus herbarius IAM $14883 .+$, Positive result; - , negative result; $\mathrm{W}$, weakly positive result.

\begin{tabular}{|c|c|c|c|c|c|c|c|c|c|}
\hline Characteristic & 1 & 2 & $3^{*}$ & 4 & 5 & $6^{*}$ & $7 \dagger$ & 8 & 9 \\
\hline Oxidase & + & - & - & - & - & - & - & + & - \\
\hline Gelatin hydrolysis & + & + & + & + & + & + & - & - & - \\
\hline Starch hydrolysis & + & + & + & + & - & + & - & - & - \\
\hline Nitrate reduced to nitrite & - & - & - & + & - & - & - & - & + \\
\hline Growth in $5 \% \mathrm{NaCl}$ & - & - & - & - & + & - & - & + & + \\
\hline \multicolumn{10}{|l|}{ Acid production from: } \\
\hline Glycerol & + & + & + & + & + & + & - & - & + \\
\hline Erythritol & - & - & - & - & + & - & - & - & - \\
\hline D-Arabinose & - & - & - & - & - & - & + & + & + \\
\hline L-Arabinose & - & + & + & + & + & + & + & + & + \\
\hline D-Xylose & - & + & + & + & - & - & + & + & + \\
\hline L-Xylose & - & - & - & - & - & - & - & + & - \\
\hline D-Galactose & - & + & + & + & + & + & + & - & + \\
\hline L-Sorbose & + & - & - & + & - & - & + & + & - \\
\hline Rhamnose & - & + & + & + & + & - & - & + & + \\
\hline Inositol & - & - & - & - & + & - & - & - & - \\
\hline Mannitol & + & + & + & + & + & + & - & + & + \\
\hline Sorbitol & - & - & - & - & + & - & + & + & - \\
\hline Methyl- $\alpha$-D-mannoside & - & - & - & + & - & - & - & - & + \\
\hline Methyl- $\alpha$-D-glucoside & + & + & - & + & - & - & + & - & + \\
\hline Amygdalin & + & - & - & - & - & - & - & - & + \\
\hline Arbutin & - & + & + & + & - & - & + & - & + \\
\hline Aesculin & + & + & - & + & - & - & + & + & + \\
\hline Salicin & + & + & + & + & - & - & + & - & + \\
\hline Cellobiose & - & + & + & + & + & + & + & - & + \\
\hline Maltose & + & + & + & + & + & + & + & - & + \\
\hline Lactose & - & + & + & + & + & + & + & - & + \\
\hline Melibiose & - & + & - & + & $\mathrm{w}$ & - & - & - & + \\
\hline Sucrose & + & + & + & + & + & + & + & - & + \\
\hline Trehalose & + & + & + & + & + & + & + & - & + \\
\hline Melezitose & - & - & + & + & - & - & + & - & + \\
\hline D-Raffinose & - & + & + & + & - & - & + & - & + \\
\hline Starch & - & + & - & + & - & $\mathrm{w}$ & - & - & - \\
\hline Glycogen & - & + & + & + & - & + & - & - & - \\
\hline Xylitol & - & - & - & + & + & - & + & - & - \\
\hline$\beta$-Gentiobiose & - & - & + & + & - & $\mathrm{w}$ & + & - & + \\
\hline D-Turanose & + & - & + & + & - & + & + & - & + \\
\hline D-Lyxose & - & - & - & - & - & - & - & + & - \\
\hline D-Tagatose & + & - & + & + & - & - & - & + & - \\
\hline D-Fucose & - & - & - & - & - & - & - & - & + \\
\hline 5-Ketogluconate & + & - & - & - & - & - & - & + & + \\
\hline
\end{tabular}

${ }^{\star}$ Data from Albuquerque et al. (2000).

$\dagger$ Data from Matsubara et al. (2002).

and the maximum-parsimony tree (Fig. 2) at bootstrap values of 81 and $87 \%$, respectively. Strain $3 \mathrm{~A}^{\mathrm{T}}$ clustered with Alicyclobacillus cycloheptanicus DSM $4006^{\mathrm{T}}$ and Alicyclobacillus herbarius $\mathrm{CP}^{\mathrm{T}}$ in the trees, however, without significant bootstrap values (21-68\%). Sulfobacillus disulfidooxidans DSM $12064^{\mathrm{T}}$ branched off from the main Alicyclobacillus cluster; however, the relative branching order was not well supported by bootstrap values. The gyrB 
Table 2. Cellular fatty acid composition of Alicyclobacillus pomorum $3 \mathrm{~A}$ and related thermoacidophilic endospore-forming bacteria

1, Alicyclobacillus pomorum $3 \mathrm{~A}^{\mathrm{T}} ; 2$, Bacillus tusciae IFO $15312^{\mathrm{T}} ; 3$, Alicyclobacillus acidocaldarius cluster; 4, Alicyclobacillus acidoterrestris cluster; 5, Alicyclobacillus cycloheptanicus DSM 4006 ; 6, Alicyclobacillus herbarius IAM $14883^{\mathrm{T}}$; TR, trace.

\begin{tabular}{|c|c|c|c|c|c|c|}
\hline \multirow[t]{2}{*}{ Fatty acid } & \multicolumn{6}{|c|}{ Composition (\%) } \\
\hline & 1 & 2 & 3 & 4 & $5^{\star}$ & $6^{*}$ \\
\hline $\mathrm{C}_{14: 0}$ & $0 \cdot 5$ & TR & & $0-1 \cdot 2$ & $0 \cdot 8$ & $0 \cdot 4$ \\
\hline $\mathrm{C}_{15: 0}$ & $0 \cdot 5$ & TR & & $0-0 \cdot 7$ & $0 \cdot 6$ & $\mathrm{TR}$ \\
\hline $\mathrm{C}_{16: 0}$ & $1 \cdot 4$ & $5 \cdot 2$ & $1 \cdot 7-3 \cdot 2$ & $1 \cdot 7-9 \cdot 7$ & $2 \cdot 4$ & $5 \cdot 1$ \\
\hline $\mathrm{C}_{17: 0}$ & TR & $1 \cdot 5$ & & & & $0 \cdot 5$ \\
\hline $\mathrm{C}_{18: 0}$ & $1 \cdot 3$ & $4 \cdot 9$ & $1 \cdot 5-2 \cdot 5$ & & $1 \cdot 3$ & $2 \cdot 4$ \\
\hline iso- $\mathrm{C}_{15: 0}$ & $19 \cdot 9$ & $1 \cdot 9$ & $1 \cdot 4-1 \cdot 7$ & $0 \cdot 5-0 \cdot 8$ & $0 \cdot 5$ & $0 \cdot 4$ \\
\hline iso- $\mathrm{C}_{16: 0}$ & $18 \cdot 3$ & $27 \cdot 5$ & $0 \cdot 8-2 \cdot 8$ & $0-0 \cdot 5$ & $1 \cdot 0$ & $3 \cdot 8$ \\
\hline iso- $\mathrm{C}_{17: 0}$ & $13 \cdot 3$ & $11 \cdot 3$ & $2 \cdot 6-5 \cdot 1$ & $1 \cdot 2-2 \cdot 0$ & $2 \cdot 7$ & $5 \cdot 6$ \\
\hline iso- $\mathrm{C}_{18: 0}$ & TR & $5 \cdot 4$ & & & & $3 \cdot 2$ \\
\hline anteiso- $\mathrm{C}_{15: 0}$ & $9 \cdot 9$ & $4 \cdot 2$ & $0 \cdot 5-1 \cdot 2$ & $0 \cdot 5-1 \cdot 1$ & TR & $\mathrm{TR}$ \\
\hline anteiso- $\mathrm{C}_{17: 0}$ & $34 \cdot 2$ & $36 \cdot 5$ & $0 \cdot 7-6 \cdot 7$ & $3 \cdot 2-6 \cdot 5$ & $1 \cdot 3$ & $3 \cdot 0$ \\
\hline$\omega$-Cyclohexane $\mathrm{C}_{17: 0}$ & & & $47 \cdot 6-52 \cdot 8$ & $62 \cdot 6-68 \cdot 4$ & & \\
\hline$\omega$-Cyclohexane $\mathrm{C}_{19: 0}$ & & & $25 \cdot 2-42 \cdot 6$ & $18 \cdot 9-23 \cdot 9$ & & \\
\hline$\omega$-Cycloheptane $\mathrm{C}_{18: 0}$ & & & & & $86 \cdot 8$ & $67 \cdot 1$ \\
\hline$\omega$-Cycloheptane $\mathrm{C}_{18: 02 \mathrm{OH}}$ & & & & & $2 \cdot 3$ & $3 \cdot 5$ \\
\hline$\omega$-Cycloheptane $\mathrm{C}_{20: 0}$ & & & & & TR & $4 \cdot 5$ \\
\hline
\end{tabular}

${ }^{\star}$ Data from Goto et al. (2002a).

gene sequence of strain $3 \mathrm{~A}^{\mathrm{T}}$ exhibited $68 \cdot 5-74 \cdot 4 \%$ identity to other strains of Alicyclobacillus species and Sulfobacillus disulfidooxidans DSM $12064^{\mathrm{T}}$. Although the phylogenetic relationships, based on GyrB amino acid sequences (382 unambiguous amino acids), were also investigated using neighbour-joining and maximum-parsimony approaches (data not shown), the topologies of the phylogenetic trees were almost identical between the trees and the accurate phylogenetic position of strain $3 \mathrm{~A}^{\mathrm{T}}$ in the cluster, especially in relation to Alicyclobacillus cycloheptanicus, Alicyclobacillus herbarius and Sulfobacillus disulfidooxidans, remained ambiguous as described for the nucleic acid data.

Table 3. DNA base compositions, DNA-DNA hybridization values and sequence similarities of $16 \mathrm{~S}$ rDNA and gyrB between Alicyclobacillus pomorum $3 A^{\top}$ and related thermo-acidophilic endospore-forming bacteria

\begin{tabular}{|c|c|c|c|c|}
\hline Species & Strain & $\begin{array}{c}\mathrm{G}+\mathrm{C} \text { content } \\
\quad(\mathrm{mol} \%)\end{array}$ & $\begin{array}{c}\text { Hybridization } \\
\text { value }(\%) \text { with } 3 A^{T}\end{array}$ & $\begin{array}{l}\text { Similarity }(\%)(16 \mathrm{~S} \\
\text { rDNA/gyrB) with } 3 \mathrm{~A}^{\mathrm{T}}\end{array}$ \\
\hline Alicyclobacillus pomorum & $3 A^{T}$ & $53 \cdot 1$ & 100 & $100 / 100$ \\
\hline Alicyclobacillus genomic species 2 & MIH-332 & $62 \cdot 5$ & 11 & $94 \cdot 0 / 68 \cdot 5$ \\
\hline Alicyclobacillus acidocaldarius subsp. acidocaldarius & ATCC $27009^{\mathrm{T}}$ & $61 \cdot 9$ & 12 & $94 \cdot 3 / 69 \cdot 4$ \\
\hline Alicyclobacillus acidocaldarius subsp. rittmannii & DSM $11297^{\mathrm{T}}$ & $62 \cdot 7$ & 10 & $94 \cdot 3 / 68 \cdot 9$ \\
\hline Alicyclobacillus hesperidum & DSM $12489^{\mathrm{T}}$ & $54 \cdot 0$ & 11 & $95 \cdot 2 / 69 \cdot 7$ \\
\hline Alicyclobacillus acidiphilus & TA $67^{\mathrm{T}}$ & $55 \cdot 6$ & 11 & $94 \cdot 3 / 71 \cdot 8$ \\
\hline Alicyclobacillus cycloheptanicus & DSM $4006^{\mathrm{T}}$ & $57 \cdot 2$ & 13 & $95 \cdot 5 / 73 \cdot 8$ \\
\hline Alicyclobacillus herbarius & DSM $13609^{\mathrm{T}}$ & $56 \cdot 2$ & 11 & $93 \cdot 6 / 74 \cdot 4$ \\
\hline Sulfobacillus disulfidooxidans & DSM $12064^{\mathrm{T}}$ & $52 \cdot 9$ & 8 & $92 \cdot 5 / 69 \cdot 9$ \\
\hline
\end{tabular}


Determining the relationship between these organisms will require sequence data from additional isolates of Alicyclobacillus and related genera.

The DNA-DNA hybridization values for strain $3 \mathrm{~A}^{\mathrm{T}}$ and phylogenetically related strains of Alicyclobacillus, Bacillus and Sulfobacillus species were 1-13\%, which was well below the $70 \%$ cut-off point recommended by Wayne et al. (1987) for the recognition of a genomic species.

According to the description of the genus Alicyclobacillus by Wisotzkey et al. (1992), the predominant membrane fatty acids of its members are $\omega$-alicyclic acids that contain six- or seven-carbon rings. These fatty acids have been suggested to play an important role in the growth of Alicyclobacillus in thermal and acidic environments (De Rosa et al., 1971; Kannenberg et al., 1984; Poralla et al., 1984; Krischke \& Poralla, 1990; Moore et al., 1997). Although the genus Sulfobacillus has also been reported to possess $\omega$-alicyclic fatty acids (Golovacheva \& Karavaiko, 1979; Dufresne et al., 1996; Norris et al., 1996), Sulfobacillus disulfidooxidans is meso-acidophilic, whereas Sulfobacillus thermosulfidooxidans, Sulfobacillus acidophilus and Sulfobacillus disulfidooxidans are thermo-acidophilic. Furthermore, Curtobacterium pusillum (Suzuki et al., 1981) and Propionibacterium cyclohexanicum (Kusano et al., 1997) also possess $\omega$-alicyclic acids; however, these organisms are neither thermophilic nor acidophilic (Propionibacterium cyclohexanicum is an acidotolerant bacterium), thus the presence of $\omega$-alicyclic acids does not necessarily relate to the physiological property of being thermo-acidophilic.

On the other hand, thermo-neutrophilic bacilli, such as Aneurinibacillus thermoaerophilus (Heyndrickx et al., 1997), Bacillus coagulans (Nazina et al., 2001), Brevibacillus thermoruber (Manachini et al., 1985), Geobacillus species (Nazina et al., 2001), Thermobacillus species (Touzel et al., 2000) and Ureibacillus species (Fortina et al., 2001), possess iso- $\mathrm{C}_{15: 0}$, anteiso- $\mathrm{C}_{15: 0}, \mathrm{C}_{16: 0}$, iso- $\mathrm{C}_{16: 0}$, iso- $\mathrm{C}_{17: 0}$ and/or anteiso$\mathrm{C}_{17: 0}$ as major cellular fatty acids. Also, mesophilic and mildly acidophilic bacilli, such as Bacillus naganoensis (Tomimura et al., 1990) and Bacillus tusciae IFO $15312^{\mathrm{T}}$ (Table 2), possess iso- $C_{14: 0}$, iso- $C_{15: 0}$, anteiso- $C_{15: 0}$, iso$\mathrm{C}_{16: 0}$, iso- $\mathrm{C}_{17: 0}$ and/or anteiso- $\mathrm{C}_{17: 0}$ as major cellular fatty acids. The predominant cellular fatty acids of strain $3 \mathrm{~A}^{\mathrm{T}}$ are iso- $\mathrm{C}_{15: 0}$, anteiso- $\mathrm{C}_{15: 0}$, iso- $\mathrm{C}_{16: 0}$, iso- $\mathrm{C}_{17: 0}$ and anteiso- $\mathrm{C}_{17: 0}$ and the fatty acid composition is relatively similar to that of Bacillus tusciae IFO $15312^{\mathrm{T}}$. Within this list of species anteiso- $\mathrm{C}_{17: 0}$ is consistently the most abundant fatty acid. However, strain $3 \mathrm{~A}^{\mathrm{T}}$ could be distinguished from Bacillus tusciae IFO $15312^{\mathrm{T}}$ by the relative percentage of iso- $\mathrm{C}_{15: 0}$, anteiso- $\mathrm{C}_{15: 0}$, iso- $\mathrm{C}_{16: 0}$ and iso$\mathrm{C}_{18: 0}$. Moreover, values of DNA-DNA hybridization and sequence similarity in both $16 \mathrm{~S}$ rDNA and $\operatorname{gyrB}$ genes between strain $3 \mathrm{~A}^{\mathrm{T}}$ and Bacillus tusciae IFO $15312^{\mathrm{T}}$ were lower than for other Alicyclobacillus species.

Although strain $3 \mathrm{~A}^{\mathrm{T}}$ does not possess any $\omega$-alicyclic fatty acids, the results of this polyphasic taxonomic analysis clearly show that this thermo-acidophilic heterotrophic endospore-forming bacterium represents a hitherto unrecognized species within the genus Alicyclobacillus. Therefore, on the basis of all data obtained, we propose that the unknown bacterium should be classified within the genus Alicyclobacillus, as Alicyclobacillus pomorum sp. nov. In addition, the results of $16 \mathrm{~S}$ rDNA and gyrB gene sequence analyses strongly suggested that Sulfobacillus disulfidooxidans is phylogenetically closely related to the genus Alicyclobacillus rather than the genus Sulfobacillus. However, Alicyclobacillus is heterotrophic while Sulfobacillus is mixotrophic, thus delineating these two genera. Further taxonomic studies are in progress to clarify phylogenetic heterogeneity within the genera Alicyclobacillus and Sulfobacillus.

\section{Emended description of genus Alicyclobacillus Wisotzkey et al. 1992}

The description of the genus Alicyclobacillus (Wisotzkey et al., 1992) is emended to reflect the following chemotaxonomic characteristic. The cellular fatty acids profile consists of $\omega$-alicyclic fatty acids and a small amount of straight- and branched-chain saturated fatty acids or only straight- and branched-chain saturated fatty acids instead of $\omega$-alicyclic fatty acids.

\section{Description of Alicyclobacillus pomorum sp. nov.}

Alicyclobacillus pomorum (po.mo'rum. L. neut. N. pomum fruit; L. gen. pl. neut. n. pomorum of fruits).

Gram-positive, but Gram-variable in old cultures, strictly aerobic, motile, endospore-forming straight rods with rounded ends $(2 \cdot 0-4 \cdot 0 \times 0 \cdot 8-1 \cdot 0 \mu \mathrm{m})$. Endospores are oval and subterminal with swollen sporangia. Colonies on BAM agar are circular and 3-4 $\mathrm{mm}$ in diameter after $48 \mathrm{~h}$ and are not pigmented. Temperature range for growth is 30 $60{ }^{\circ} \mathrm{C}$; optimum growth temperature is $45-50{ }^{\circ} \mathrm{C}$. $\mathrm{pH}$ optimum is $4 \cdot 5-5 \cdot 0$; growth does not occur at $\mathrm{pH} 2 \cdot 5$ or 6.5. Growth factors are not required, but growth is further increased by adding yeast extract to the inorganic medium. The generation time is $1.5 \mathrm{~h}$. Oxidase- and catalase-positive, but does not reduce nitrate to nitrite. Aesculin, gelatin and starch are hydrolysed, but arbutin, phenylalanine and tyrosine are not. Acid is produced from glycerol, ribose, D-glucose, D-fructose, D-mannose, L-sorbose, mannitol, methyl- $\alpha$-D-glucoside, amygdalin, aesculin, salicin, maltose, sucrose, trehalose, D-turanose, D-tagatose and 5-ketogluconate. The major fatty acids are iso- $\mathrm{C}_{15: 0}$, anteiso- $\mathrm{C}_{15: 0}$, iso- $\mathrm{C}_{16: 0}$, iso- $\mathrm{C}_{17: 0}$ and anteiso$\mathrm{C}_{17: 0}$. The main quinone is menaquinone 7 . The $\mathrm{G}+\mathrm{C}$ content is $53 \cdot 1 \mathrm{~mol} \%$. Type strain is strain $3 \mathrm{~A}^{\mathrm{T}}$ (=DSM $\left.14955^{\mathrm{T}}=\operatorname{IAM} 14988^{\mathrm{T}}\right)$.

\section{Acknowledgements}

We thank Professor Trüper for his valuable advice on nomenclature and Yuko Kato for her excellent technical assistance. 


\section{References}

Adachi, T., Mizuuchi, M., Robinson, E. A., Appella, E., O'Dea, M. H., Gellert, M. \& Mizuuchi, K. (1987). DNA sequence of the E. coli gyrB gene: application of a new sequencing strategy. Nucleic Acids Res 15, 771-784.

Albuquerque, L., Rainey, F. A., Chung, A. P., Sunna, A., Nobre, M. F., Grote, R., Antranikian, G. \& De Costa, M. S. (2000). Alicyclobacillus hesperidum sp. nov. and a related genomic species from solfataric soils of São Miguel in the Azores. Int J Syst Evol Microbiol 50, 451-457.

Brosius, J., Palmer, M. L., Kennedy, P. J. \& Noller, H. F. (1978). Complete nucleotide sequence of the 16S ribosomal RNA gene from Escherichia coli. Proc Natl Acad Sci U S A 75, 4801-4805.

Darland, G. \& Brock, T. D. (1971). Bacillus acidocaldarius sp. nov., an acidophilic thermophilic spore-forming bacterium. J Gen Microbiol 67, 9-15.

Deinhard, G., Blanz, P., Poralla, K. \& Altan, E. (1987a). Bacillus acidoterrestris sp. nov., a new thermotolerant acidophile isolated from different soils. Syst Appl Microbiol 10, 47-53.

Deinhard, G., Saar, J., Krischke, W. \& Poralla, K. (1987b). Bacillus cycloheptanicus sp. nov., a new thermoacidophile containing $\omega$ cycloheptane fatty acids. Syst Appl Microbiol 10, 68-73.

De Rosa, M., Gambacorta, A., Minale, L. \& Bu'Lock, J. D. (1971). Cyclohexane fatty acids from a thermophilic bacterium. Chem Commun 1019, 1334.

Dufresne, S., Bousquet, J., Boissinot, M. \& Guay, R. (1996). Sulfobacillus disulfidooxidans sp. nov., a new acidophilic, disulfideoxidizing, Gram-positive, spore-forming bacterium. Int $J$ Syst Bacteriol 46, 1056-1064.

Ezaki, T., Hashimoto, Y. \& Yabuuchi, E. (1989). Fluorometric deoxyribonucleic acid-deoxyribonucleic acid hybridization in microdilution wells as an alternative to membrane filter hybridization in which radioisotopes are used to determine genetic relatedness among bacterial strains. Int J Syst Bacteriol 39, 224-229.

Felsenstein, J. (1985). Confidence limits on phylogenies: an approach using the bootstrap. Evolution 30, 783-791.

Fortina, M. G., Pukall, R., Schumann, P., Mora, D., Parini, C., Manachini, P. L. \& Stackebrandt, E. (2001). Ureibacillus gen. nov., a new genus to accommodate Bacillus thermosphaericus (Anderson et al., 1995), emendation of Ureibacillus thermosphaericus and description of Ureibacillus terrenus sp. nov. Int J Syst Evol Microbiol 51, 447-455.

Golovacheva, R. S. \& Karavaiko, G. I. (1979). Sulfobacillus - a new genus of spore-forming thermophilic bacteria. Microbiology (English translation of Mikrobiologiya) 47, 658-665.

Goto, K., Omura, T., Hara, Y. \& Sadaie, Y. (2000). Application of the partial $16 \mathrm{~S}$ rDNA sequence as an index for rapid identification of species in the genus Bacillus. J Gen Appl Microbiol 46, 1-8.

Goto, K., Matsubara, H., Mochida, K., Matsumura, T., Hara, Y., Niwa, M. \& Yamasato, K. (2002a). Alicyclobacillus herbarius sp. nov., a novel bacterium containing $\omega$-cycloheptane fatty acids, isolated from herbal tea. Int J Syst Evol Microbiol 52, 109-113.

Goto, K., Tanimoto, Y., Tamura, T., Mochida, K., Arai, D., Asahara, M., Suzuki, M., Tanaka, H. \& Inagaki, K. (2002b). Identification of thermoacidophilic bacteria and a new Alicyclobacillus genomic species isolated from acidic environments in Japan. Extremophiles 6, 333-340.

Goto, K., Mochida, K., Asahara, M., Suzuki, M. \& Yokota, A. (2002c). Application of the hypervariable region of the 16S rDNA sequence as an index for the rapid identification of species in the genus Alicyclobacillus. J Gen Appl Microbiol 48, 243-250.

Heyndrickx, M., Lebbe, L., Vancanneyt M. \& 7 other authors (1997). A polyphasic reassessment of the genus Aneurinibacillus, reclassification of Bacillus thermoaerophilus (Meier-Stauffer et al., 1996) as Aneurinibacillus thermoaerophilus comb. nov., and emended description of $A$. aneurinilyticus corrig., A. migulanus, and $A$. thermoaerophilus. Int J Syst Bacteriol 47, 808-817.

Hippchen, B., Roll, A. \& Poralla, K. (1981). Occurrence in soil of thermo-acidophilic bacilli possessing $\omega$-cyclohexane fatty acids and hopanoids. Arch Microbiol 129, 53-55.

Hiraishi, A., Inagaki, K., Tanimoto, Y., Iwasaki, M., Kishimoto, N. \& Tanaka, H. (1997). Phylogenetic characterization of a new thermoacidophilic bacterium isolated from hot spring in Japan. J Gen Appl Microbiol 43, 295-304.

Kannenberg, E., Blume, A. \& Poralla, K. (1984). Properties of $\omega$-cyclohexane fatty acids in membranes. FEBS 172, 331-334.

Kasai, H., Tamura, T. \& Harayama, S. (2000). Intrageneric relationship among Micromonospora species deduced from gyrBbased phylogeny and DNA relatedness. Int J Syst Evol Microbiol 50, 127-134.

Kimura, M. (1980). A simple method for estimating evolutionary rates of base substitution through comparative studies of nucleotide sequence. J Mol Evol 16, 111-120.

Krischke, W. \& Poralla, K. (1990). Properties of Bacillus acidocaldarius mutants deficient in $\omega$-cyclohexyl fatty acid biosynthesis. Arch Microbiol 153, 463-469.

Kumar, S., Tamura, K., Jakobsen, I. B. \& Nei, M. (2001). MEGA2: Molecular evolutionary genetics analysis software. Bioinformatics 17, 1244-1245.

Kusano, K., Yamada, H., Niwa, M. \& Yamasato, K. (1997). Propionibacterium cyclohexanicum sp. nov., a new acid-tolerant $\omega$-cyclohexyl fatty acid-containing propionibacterium isolated from spoiled orange juice. Int J Syst Bacteriol 47, 825-831.

Lake, J. A. (1987). A rate-independent technique for analysis of nucleic acid sequences: evolutionary parsimony. Mol Biol Evol 4, 167-191.

Manachini, P. L., Fortina, M. G., Parini, C. \& Craveri, R. (1985). Bacillus thermoruber sp. nov. rev., a red-pigmented thermophilic bacterium. Int J Syst Bacteriol 35, 493-496.

Matsubara, H., Goto, K., Matsumura, T., Mochida, K., Iwaki, M., Niwa, M. \& Yamasato, K. (2002). Alicyclobacillus acidiphilus sp. nov., a new thermo-acidophilic $\omega$-alicyclic fatty acid-containing bacterium isolated from acidic beverages. Int J Syst Evol Microbiol 52, 1681-1685.

Moore, B. S., Walker, K., Tornus, I., Handa, S., Poralla, K. \& Floss, H. G. (1997). Biosynthetic studies of $\omega$-cycloheptyl fatty acids in Alicyclobacillus cycloheptanicus. Formation of cycloheptanecarboxylic acid from phenylacetic acid. J Org Chem 62, 2173-2185.

Nazina, T. N., Tourova, T. P., Poltaraus, A. B. \& 8 other authors (2001). Taxonomic study of aerobic thermophilic bacilli: description of Geobacillus subterraneus gen. nov., sp. nov. and Geobacillus uzenensis sp. nov. from petroleum reservoirs and transfer of Bacillus stearothermophilus, Bacillus thermocatenulatus, Bacillus thermoleovorans, Bacillus kaustophilus, Bacillus thermoglucosidasius and Bacillus thermodenitrificans to Geobacillus as the new combinations G. stearothermophilus, G. thermocatenulatus, G. thermoleovorans, G. kaustophilus, G. thermoglucosidasius and G. thermodenitrificans. Int J Syst Evol Microbiol 51, 433-446.

Nicolaus, B., Improta, R., Manca, C. M., Lama, L., Esposito, E. \& Gambacorta, A. (1998). Alicyclobacilli from an unexplored geothermal soil in Antarctica: Mount Rittmann. Polar Biol 19, 133-141.

Norris, P. R., Clark, D. A., Owen, J. P. \& Waterhouse, S. (1996). Characteristics of Sulfobacillus acidophilus sp. nov. and other moderately thermophilic mineral-sulphide-oxidizing bacteria. Microbiology 142, 775-783. 
Poralla, K., Härtner, T. \& Kannenberg, E. (1984). Effect of temperature and $\mathrm{pH}$ on the hopanoid content of Bacillus acidocaldarius. FEBS Microbiol Lett 23, 253-256.

Saitou, N. \& Nei, M. (1987). The neighbor-joining method: A new method for reconstruction of phylogenetic trees. Mol Biol Evol 4, 406-425.

Suzuki, K., Saito, K., Kawaguchi, A., Okuda, S. \& Komagata, K. (1981). Occurrence of $\omega$-cyclohexyl fatty acids in Curtobacterium pusillum strains. J Gen Appl 27, 261-266.

Tamaoka, J. \& Komagata, K. (1984). Determination of DNA base composition by reverse-phase high-performance liquid chromatography. FEMS Microbiol Lett 25, 125-128.

Thompson, J. D., Higgins, D. G. \& Gibson, T. J. (1994). CLUSTAL W: Improving the sensitivity of progressive multiple sequence weighing, position-specific gap penalties and weight matrix choice. Nucleic Acid Res 76, 4350-4354.

Tomimura, E., Zeman, N. W., Frankiewicz, J. R. \& Teague, W. M. (1990). Description of Bacillus naganoensis sp. nov. Int J Syst Bacteriol 40, 123-125.

Touzel, J. P., O'Donohue, M., Debeire, P., Samain, E. \& Breton, C. (2000). Thermobacillus xylanilyticus gen. nov., sp. nov., a new aerobic thermophilic xylan-degrading bacterium isolated from farm soil. Int J Syst Evol Microbiol 50, 315-320.
Tsuruoka, N., Isono, Y., Shida, O., Hemmi, H., Nakayama, T. \& Nishino, T. (2003). Alicyclobacillus sendaiensis sp. nov., a novel acidophilic, slightly thermophilic species isolated from soil in Sendai, Japan. Int J Syst Evol Microbiol 53, 1081-1084.

Uchino, F. \& Doi, S. (1967). Acido-thermophilic bacteria from thermal waters. Agric Biol Chem 31, 817-822.

Wayne, L. G., Brenner, D. J., Colwell, R. R. \& 9 other authors (1987). International Committee on Systematic Bacteriology. Report of the ad hoc committee on reconciliation of approaches to bacterial systematics. Int J Syst Bacteriol 37, 463-464.

Wisotzkey, J. D., Jurtshuk, J. R. P., Fox, G. E., Deinhard, G. \& Poralla, K. (1992). Comparative sequence analyses on the $16 \mathrm{~S}$ rRNA (rDNA) of Bacillus acidocaldarius, Bacillus acidoterrestris, and Bacillus cycloheptanicus and proposal for creation of a new genus, Alicyclobacillus gen. nov. Int J Syst Bacteriol 42, 263-269.

Yamamoto, S. \& Harayama, S. (1995). PCR amplification and direct sequencing of gyrB genes with universal primers and their application to the detection and taxonomic analysis of Pseudomonas putida strains. Appl Environ Microbiol 61, 1104-1109.

Yamazaki, K., Tezuka, H. \& Shinano, H. (1996). Isolation and identification of Alicyclobacillus acidoterrestris from acid beverages. Biosci Biotechnol Biochem 60, 543-545. 